\title{
PENULISAN KARYA TULIS ILMIAH MAHASISWA DENGAN MEDIA APLIKASI PENGOLAH KATA
}

\author{
Fajar Kurniadi \\ Universitas Indraprasta PGRI \\ E-mail: fajar.kurniadi@unindra.ac.id
}

\begin{abstract}
ABSTRAK
Menulis merupakan kemampuan wajib mahasiswa. Namun, menulis merupakan keterampilan yang sulit dikuasai. Salah satu faktor lemahnya keterampilan menulis adalah keterampilan membaca. Keterampilan membaca memang memengaruhi keterampilan menulis, keduanya keterampilan tersebut mempunyai kaitan yang berbanding lurus. Tidak hanya membaca, kemampuan menulis pun akan membaik jika rajin menulis. Salah satunya adalah menulis karya ilmiah. Pembiasaan menulis dengan kaidah penulisan karya ilmiah akan membuat kesulitan itu semakin hilang. Penelitian ini dilakukan dengan membiasakan mahasiswa membuat karya tulis dengan terorganisasi sehingga menjadi efektif. Tujuan penelitian ini adalah menilai keefektifan sebuah tidakan kecil dan nyata guna meningkatkan keandalan menulis karya ilmiah mahasiswa. Penelitian ini dilakukan dalam waktu 6 (enam) bulan dengan 385 mahasiswa. Hasil penelitian ini adalah mengorganisasikan karya ilmiah dengan aplikasi pengolah kata dinilai efektif dengan raihan $98,7 \%$ responden menyatakan bahwa perilaku yang diberikan dapat mengefektifkan proses menulis karya ilmiah. Kelanjutan dari proses ini adalah penulisan tugas akhir pada semester berikutnya.
\end{abstract}

Kata kunci: efektivitas, menulis, karya ilmiah, aplikasi

\section{STUDENTS' SCIENTIFIC PAPER WRITINGS USING WORD PROCESSING APPLICATION MEDIA}

\begin{abstract}
Writing is a compulsory capability for students. However, writing is a skill that is difficult to acquire. One of the weakness that affect the writing skill is reading skill. Reading skill influences writing skill, both skills have a connection that is equivalent one another. Not only reading, writing skill will get better if students write diligently. One of it is writing scientific paper. Conditioning writing using the rules of writing scientific paper will make the difficulties slowly disappear. This research is done by conditioning the students that made scientific paper with being organized so it become effective. The purpose of the research is to evaluate the effectiveness of a small act and real in order to increase the reliability of students' scientific paper writing skill. The
\end{abstract}


research is concluded in 6 months with 385 students. The result of the research is that organizing scientific paper using word processor application is considered effective with 98.7 percent respondents said that the given treatment can make the process of writing scientific paper effective. The continuity of the process is final writing project in the next semester.

Keywords: effectiveness, writings, scientific paper, application

\section{PENDAHULUAN}

Semakin banyak membaca akan berbanding lurus dengan semakin baiknya kemampuan menulis. Namun, di Indonesia, kegiatan membaca masih jauh tertinggal dari kegitan berbicara. Gewati (2016) yang menginformasikan bahwa Indonesia masih menempati urutan ke 60 dalam hal minat baca. Hal ini masih memperihatinkan. Melihat kenyataan ini, mutlak, pembiasaan membaca sejak dini harus dilakukan. Upaya itu pun sebenarnya sudah digalakkan dengan mulai tumbuhnya rumah-rumah baca, perpustakaan keliling, bazar buku, atau menggratiskan buku-buku elektronik untuk dapat diunduh dan dibaca melalui gawai. Menyinggung tentang gawai, agaknya penggunaan gawai lebih banyak untuk keperluan lain selain membaca. Mungkin inilah penyebab meskipun banyak sumber digital, namun minat baca masih rendah.

Karya ilmiah adalah hal yang tidak asing bagi mahasiswa. Sejak baru menyandang status mahasiswa saja, mereka sudah dihadapkan dengan berbagai tugas seperti observasi, menganalisis, mengkritisi, dan lainnya yang pada akhirnya adalah pembuatan karya ilmiah sebagai laporan. Hal ini pun dinyatakan Wahyuni (2016) kemampuan pemahaman bacaan, kemampuan berpikir kritis, dan pengaturan diri dapat dieksplorasi pada mahasiswa tingkat awal untuk meningkatkan kemampuan menulis ilmiah. 
Karya ilmiah bermula dari adanya masalah. Untuk dapat memecahkan masalah, peneliti harus memahami asal-muasal masalah itu dengan mencari banyak teori. Teori yang terkumpul disimpulkan dan membentuk sebuah pemahaman baru. Pemahaman baru tersebut pun harus dipadukan dengan data lapangan agar tidak hanya berpandangan sempit. Data lapangan dapat diambil dengan observasi, penyebaran kuesioner, wawancara, dan lainnya. Data yang telah diperoleh lalu dipadukan dengan teori dan menghasilkan simpulan baru. Dari simpulan ini, peneliti harus menarik kaitan antara data dan fakta untuk dapat menemukan solusi.

Karya ilmiah mempunyai beragam jenis, di antaranya artikel, makalah, skripsi, tesis, dan disertasi. Jenis karya ilmiah tersebut mempunyai ciri khas dan kegunaan yang berbeda. Secara fisik, mereka mempunyai kedalaman yang berbeda. Artikel adalah karya ilmiah yang ditampilkan secara sederhana. Dari jumlah fisiknya, artikel mempunyai minimal 10-20 halaman atau tidak lebih dari 5000 kata. Artikel pun berpotensi dimuat dalam jurnal sebagai publikasi ilmiah. Selanjutnya, makalah mempunyai fisik yang lebih banyak dibanding artikel. Makalah mempunyai bab dan subbab yang terstruktur, jelas, dan runtut. Begitu pula untuk skripsi, tesis, dan disertasi yang digunakan untuk keperluan menyelesaikan studi di perguruan tinggi. Kompleksitas skripsi, tesis, dan disertasi pun meningkat mengikuti jenjang studinya (Winarsih \& Sulistyowati, 2016).

Usman (2008) mengungkapkan bahwa cara penulisan, karya tulis ilmiah harus tunduk pada gaya selingkung di lembaga induknya. Adapun syarat keilmiahan suatu karya yaitu menyajikan fakta objektif, ditulis secara cermat, tepat, benar, jujur, dan tidak bersifat tekanan, serta disusun secara sistematis, menyajikan penalaran sebabakibat/akibat-sebab, mengandung pandangan peneliti, dan tanpa manipulasi. 
Di perguruan tinggi, menulis merupakan sebuah keharusan. Sejak masuk hingga akan lulus, mahasiswa harus berkutat pada keterampilan menulis. Terlebih bagi mahasiswa tingkat akhir yang harus membuat tugas akhir/skripsi. Penelitian ini bertujuan meraih informasi mendalam mengenai minat baca, minat tulis, menulis karya ilmiah, dan menggunakan aplikasi pengolah kata agar karya tulis mahasiswa khususnya skripsi menjadi lebih efektif. Skripsi adalah salah satu tugas akhir yang dikerjakan mahasiswa tingkat akhir untuk meraih gelar sarjana. Terkadang, skripsi dianggap sebagai hal menakutkan atas dasar cerita mahasiswa terdahulu. Pemahaman menulis skripsi adalah mudah harus ditanamkan sejak mahasiswa menempuh studinya di semester awal.

\section{METODE}

Metode yang dilakukan dalam penelitian ini adalah metode kualitatif dengan pendekatan deskriptif analitik. Peneltiain kualitatif lebih menekankan pada analisis empirik yang diambil dari berbagai sumber di masyarakat. Populasi penelitian ini adalah mahasiswa sebanyak delapan kelas. Sampel yang diambil dalam penelitian ini adalah delapan dari dua puluh dua kelas.

\section{HASIL DAN PEMBAHASAN}

\section{Digitalisasi Tulisan}

Sebelum melakukan penelitian ini, penelti telah melakukan penelitian mengenai mengefektifkan kemampuan menulis mahasiswa dengan metode menulis buku harian, hasilnya pun memuaskan. Sebanyak $83 \%$ responden mampu melakukannya dan membuat gairah menulis mereka menjadi semakin kuat. Selanjutnya, kendala lain 
ditemukan saat mereka akan menulis karya ilmiah, yakni masalah mendigitalkan tulisan. Mahasiswa sudah akrab dengan gawai seperti smartphone, laptop, dan komputer. Namun, tidak piawai menggunakannya dengan efektif. Gawai diciptakan untuk memudahkan kerja manusia, bukan untuk menyulitkan. Tetapi, yang terjadi, gawai justru menjadi beban dan menyulitkan. Komputer canggih hanya digunakan untuk menonton film daring atau mengetik tugas kuliah, itu pun tidak maksimal.

Untuk itu, mahasiswa diminta menyalin seluruh catatan hariannya dalam gawai, utamanya laptop. Usai menyalinnya ke laptop, tenyata banyak yang tidak paham, utamanya masalah pembuatan sitasi, halaman, dan hal yang standar. Mungkin ini dianggap hal yang sepele dan tidak bermanfaat serta membuang banyak tenaga. Tetapi, inilah yang terjadi, mahasiswa tidak mampu menggunakan aplikasi pengolah kata dengan baik sehingga terjadi kesalahan fatal dalam penulisan karya ilmiah. Salah satunya adalah ketidakmampuan pengelolaan kutipan sehingga banyak kutipan yang tak dilengkapi dengan daftar pustaka. Jika ini didiamkan, maka akan terjadi pelanggaran hukum yakni plagiat. Undang-Undang Nomor 19 tahun 2002 tentang Hak Cipta. sebagaimana undang-undang yang mengatur tersebut plagiat merupakan tindakan pidana yang tertulis "Hak Cipta merupakan hak eksklusif bagi Pencipta atau Pemegang Hak Cipta untuk mengumumkan atau memperbanyak Ciptaannya, yang timbul secara otomatis setelah suatu ciptaan dilahirkan tanpa mengurangi pembatasan menurut peraturan perundang-undangan yang berlaku" dan sanksinya tertuang pada pasal 79 ayat 1 dengan bunyi "Barangsiapa dengan sengaja dan tanpa hak melakukan perbuatan sebagaimana dimaksud dalam Pasal 2 ayat (1) atau Pasal 49 ayat (1) dan ayat (2) dipidana dengan pidana penjara masing-masing paling singkat 1 (satu) bulan dan/atau denda paling sedikit Rp 1.000.000,00 (satu juta rupiah), atau pidana penjara paling lama 
7 (tujuh) tahun dan/atau denda paling banyak Rp 5.000.000.000,00 (lima miliar rupiah)" Adapun hal yang dilindungi hak ciptanya diatur dalam pasal 12 Nomor 1 butir a dengan bunyi "Dalam Undang-undang ini Ciptaan yang dilindungi adalah Ciptaan dalam bidang ilmu pengetahuan, seni, dan sastra, yang mencakup buku, Program Komputer, pamflet, perwajahan (lay out) karya tulis yang diterbitkan, dan semua hasil karya tulis lain “.

Perlakuan pertama yang diambil adalah pretest. Mahasiswa diminta menulis kegiatan dalam satu hari menggunakan aturan-aturan seperti batas pias, penggunaan gambar, tabel, dan penggunaan ejaan bahasa Indonesia. Setelah proses pengumpulan, ternyata masih banyak yang tidak paham mengenai pias, penyempurnaan gambar dan tabel sesuai dengan ketentuan.

Perlakuan kedua, pemberian informasi mengenai hal yang harus dan tidak boleh dilakukan saat menulis karya ilmiah. Pemberian informasi secara langsung dengan mendemontrasikan cara membuat pias, mengatur halaman tanpa membuat fail baru, menyusun gaya selingkung, dan membuat laptop menjadi laptop. Maksudnya, terkadang, benda canggih bernama laptop yang dibeli dan dihargai dengan harga yang tinggi dengan segala kecanggihannya diperlakukan bak barang tak bernilai dan tidak canggih. Kecanggihan gawai harus diimbangi dengan kecerdasan penggunanya.

Perlakuan ketiga adalah pengamatan dan penilaian. Setelah dilakukan perlakuan di atas, mahasiswa merasa senang karena mampu mengelola tulisan mereka dengan mengikuti kecanggihan gawai dan laptopnya. Hanya waktu lah yang dapat menjadi pengadil bagi keilmuan mereka. Mengamati setiap perilaku mahasiswa dalam menerjemahkan maksud peneliti. Saat tulisan ini dibuat, para mahasiswa sedang menjalankan mata kuliah seminar proposal yang menuntut pengerjaan penulisan karya 
ilmiah secara canggih dan matang. Tidak lagi membuatnya dengan manual dan merepotkan penulisnya.

Hal yang tidak kalah penting dalam penulisan karya ilmiah adalah pengelolaan kutipan. Mengelola kutipan bermakna mulai dari pemilihan, penyesuaian, penempatan, penulisanya dalam tubuh wacana, dan pencantumannya dalam daftar pustaka.

\section{Efektivitas Sitasi}

Proses memilih bahan kutipan menjadi bagian utama dalam penulisan karya ilmiah. Jika masukannya baik, maka keluarannya pun baik. Oleh karenanya, kutipan pun harus diambil dari tulisan yang bermutu dan mutakhir. Tulisan yang cocok dengan syarat tersebut adalah jurnal yang mempunyai tingkat kemutakhiran yang baik. Jurnal diterbitkan berkala antara dua kali setahun atau lebih akan sangat baik menjadi rujukan kutipan. Bukan bermaksud meremehkan buku sebagai sumber acuan, tetapi buku mempunyai kelemahan rumitnya proses revisi dan terkadang membutuhkan waktu yang lama untuk menunggu revisinya terbit.

Kembali membahas jurnal, jurnal yang baik adalah mempunyai ISSN (International Standard Serial Number). Lembaga Ilmu Pengetahuan Indonesia (LIPI) adalah lembaga yang menerbitkan ISSN di Indonesia. Melalui laman http://issn.lipi.go.id/ pengunjung dapat memperoleh identitas terbitan berkala yang dikelola LIPI. Terbitan berkala yang baik, termasuk jurnal, harus memiliki ISSN sebagai legalitas dan ketertiban administrasi di LIPI. Jika jurnal sudah memiliki ISSN, maka sudah dapat dijadikan acuan atau sumber rujukan.

Setelah mendapatkan jurnal yang baik, kelola dengan aplikasi pengelola kutipan seperti Mendeley, Zetero, atau Endnote (MZE). Pada penelitian ini, ketiganya tidak 
digunakan karena memikirkan tingkat kompatibel dengan gawai mahasiswa. Penelitian ini menggunakan aplikasi pengolah kata bawaan Windows yakni Microsoft Word (MW) di mana aplikasi ini mempunyai sebuah fitur mengelola kutipan. Meskipun belum seandal MZE, MW masih dapat memperlakukan kutipan dengan baik. Pengorganisasian kutipan pada MW dapat dilakukan jika fail tidak terpisah. Terkadang, penulisan karya ilmiah dipisahkan antara bab satu dengan yang lain. Jika ini dilakukan, fitur pengelola kutipan MW tidak akan dapat digunakan. Cara kerjanya adalah dengan mengklik References pada menu bar, setelah itu akan tampil banyak fitur yakni Table of Content, Footnotes, Citation \& Bibliography, Captions, Index, dan Table of Authorities. Untuk mengelola kutipan dan daftar pustaka, maka arahkan perhatian hanya pada fitur Citation \& Bibliography. Sebelum menulis sumber kutipan, perhatikanlah gaya penulisan kutipan dan daftar pustaka dengan melihat tombol Style. Berbagai gaya penulisan disajikan seperti APA Fifth Edition, Chicago Fiftheenth Edition, BG7714 2005, GOST - Name Soft, GOST - Title Short, ISO 690 - First Element adn Date, ISO 690 - Numerical Reference, MLA Sixth Edition, SISTO2, dan Turabian Sixth Edition. Setelah mengetahui menggunakan tipe tulisan sesuai keperluan, barulah menulis kutipan sesuai sumber. Untuk menulis sumber kutipan, tekan fitur Insert Citation lalu Add New Source.

Terdapat berbagai fitur di dalamnya, penulis tinggal menentuken tipe sumber acuan kutipan. Sumber acuan yang disediakan adalah buku, jurnal, prosiding, laporan, web site, seni, film, wawancara, kasus, dan lainnya. Jika sumber acuannya adalah buku, maka hal yang harus dilengkapi adalah penulis, judul buku, tahun, kota, dan penerbit. Setelah selesai mengisi hal yang dibutuhkan, tekanlah tombol OK dan akan muncul 
sumber kutipan tersebut. Penulis tinggal mencantumkan kata yang ingin dikutip dengan penyesuaian gaya selingkung.

Jika penulisan sumber sudah selesai dilakukan, selanjutnya adalah pengorganisasian daftar pustaka. Jangan sampai kutipan tidak dilengkapi daftar pustaka, atau sebaliknya. Masih pada fitur Citation \& Bibliography, sekarang tekanlah fitur Bibliography lalu beberapa saat kemudian akan muncul daftar pustaka yang sudah sesuai dengan gaya ketentuan penulisan. Biasanya, gaya penulisannya adalah APA (American Psychological Association) dengan berbagai penambahan atau pengurangan sesuai gaya selingkung instansi.

Setelah melakukan kegiatan ini, penulisan karya ilmiah mahasiswa menjadi terorganisasi dan efektif. Ditambah lagi, tidak akan terjerat kasus hukum karena menulis hal yang tidak sesuai dengan Undang-Undang. Selanjutnya, mahasiswa diminta mengikuti jajak pendapat berkaitan dengan proses penulisan karya ilmiah dengan mengisi kuesioner digital. Kuesioner digital itu disebarkan kepada mahasiswa yang ikut program ini dengan mengikuti tautan https://goo.gl/forms/tVoffXIOsrvXRH3v1 selama dua minggu dan hasilnya adalah sebagai berikut.

Apakah proses pengorganisasian tulisan yang dilakukan pada mata kuliah Bahasa Indonesia 2 dapat membantu Anda dalam menulis karya ilmiah? 385 tanggapan

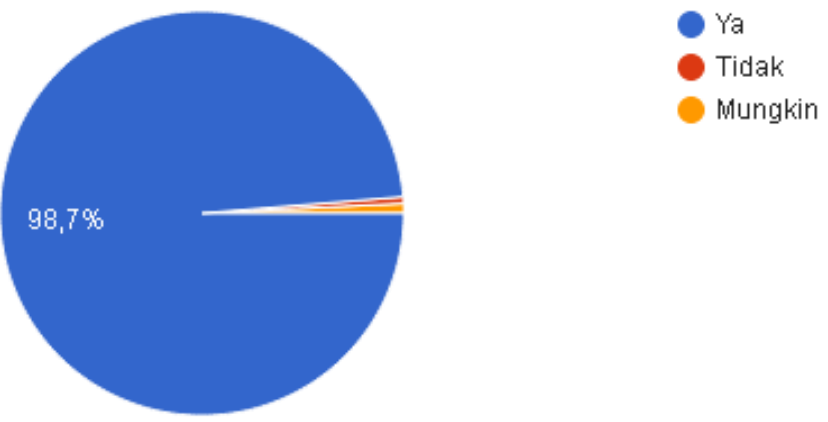

AKSIS: Jurnal Pendidikan Bahasa dan Sastra Indonesia 
Sumber:

https://docs.google.com/document/d/1vi21f4t8HfFeeC52MRu5Pyi_We_s3NCP2f5zc8m9ItQ/edi

$\underline{\mathrm{t} \#}$

Berdasarkan data yang diambil dari kuesioner yang diisi secara anonimi di atas, bahwa proses pengorganisasian tulisan dalam penulisan karya ilmiah dinyatakan efektif. Selain itu, kemampuan menulis karya ilmiah mahasiswa masih rendah dan dibutuhkan pelatihan menulis karya ilmiah untuk mahasiswa. Proses pengorganisasian tulisan dengan aplikasi Microsoft Office Word merupakan salah satu cara efektif untuk mengefektifkan penulisan karya ilmiah.

\section{KESIMPULAN}

Berdasarkan penelitian yang telah dilakukan, maka dapat disimpulkan bahwa kemampuan menulis karya ilmiah mahasiswa yang masih rendah merupakan persoalan kompleks yang perlu dipecahkan dengan tahapan-tahapan yang sitematis, penggunaan aplikasi pengolah kata yang tersedia secara gratis dari berbagai provider hanyalah salah satu cara untuk mengefektifkan penulisan referensi dan daftar pustaka pada karya ilmiah, dan untuk memaksimalkan penggunaan aplikasi mahasiswa perlu diberikan pemahaman konsep terlebih dahulu.

\section{UCAPAN TERIMA KASIH}

Peneliti mengucapkan terima kasih kepada seluruh pihak yang telah mendukung penelitian ini terutama rekan dosen dan mahasiswa di Universitas Indraprasta PGRI. Penghargaan terbesar atas hasil pencapaian ini, peneliti sampaikan kepada istri dan anak tercinta. 


\section{DAFTAR PUSTAKA}

Gewati, M. (2016). Minat baca Indonesia ada di urutan ke-60 dunia. Diakses 2 Agustus 2017.

Kompas.com. http://edukasi.kompas.com/read/2016/08/29/07175131/minat.baca.indonesia.ada .di.urutan.ke-60.dunia

Usman, H. (2008). Manajemen: Teori, praktik, dan riset pendidikan (2ed.). Jakarta: Bumi Aksara.

Wahyuni, E. S. (2016). Pengaruh kemampuan berpikir kritis, pemahaman bacaan, dan pengaturan diri terhadap kemampuan menulis ilmiah. Ranah, 4 (1), 120-132.

Winarsih, E. \& Sulistyowati, R. (2016). Penerapan pendekatan saintifik dalam Mata Kuliah Umum Bahasa Indonesia untuk menumbuhkan budaya menulis mahasiswa IKIP PGRI Madiun. Widyabastra, 141-157. 